Published in

Comptes Rendus Palevol 3(3): 199-208, 2004

which should be cited to reference this work

\title{
A basal sauropod dinosaur from the Early Jurassic of Morocco
}

\author{
Ronan Allain ${ }^{\mathrm{a}, \mathrm{b}, *}$, Najat Aquesbi ${ }^{\mathrm{c}}$, Jean Dejax ${ }^{\mathrm{a}}$, Christian Meyer ${ }^{\mathrm{d}}$, \\ Michel Monbaron ${ }^{\mathrm{e}}$, Christian Montenat ${ }^{\mathrm{f}}$, Philippe Richir ${ }^{\mathrm{a}}$, Mohammed Rochdy ${ }^{\mathrm{c}}$, \\ Dale Russell ${ }^{\mathrm{g}}$, Philippe Taquet ${ }^{\mathrm{a}}$ \\ ${ }^{a}$ Laboratoire de paléontologie, département «Histoire de la Terre », Muséum national d'histoire naturelle, UMR 8569 CNRS, \\ 8, rue Buffon, 75005 Paris, France \\ ${ }^{b}$ Université Rennes 1, Geosciences, Campus de Beaulieu, av. du Général-Leclerc, 35042 Rennes cedex, France \\ c Institut Agdal, ministère de l'Énergie et des Mines, BP 6 208, Rabat, Morocco \\ ${ }^{d}$ Naturhistorisches Museum Basel, Augustinergasse 2, CH-4001 Basel, Switzerland \\ e Département de Géosciences, université de Fribourg, chemin du Musée 4, CH-1700 Fribourg, Switzerland \\ ${ }^{f}$ Institut géologique Albert-de-Lapparent (IGAL), 13, bd de l'Hautil, 95092 Cergy-Pontoise, France \\ ${ }^{g}$ North Carolina Museum of Natural Sciences, and Department of Marine, Earth and Atmospheric Sciences, \\ North Carolina State University, Box 8208, Raleigh, NC 27695, USA \\ Received 12 February 2004; accepted 15 March 2004
}

Available online 30 April 2004

\begin{abstract}
Continental strata of Early Jurassic age are seldom exposed, and little is known of the history of sauropod dinosaurs prior to the Middle Jurassic radiation of neosauropods. Well-preserved skeletons and skulls have not been recovered from strata older than the Middle Jurassic. Here we report, in the Early Jurassic of the Moroccan High Atlas, the discovery of the skeleton, including cranial material, of a new vulcanodontid sauropod. Tazoudasaurus naimi n.g., n.sp. represents with Vulcanodon the sister group of the eusauropods and the most complete basal sauropod material available to date.
\end{abstract}

\section{Résumé}

Parce que les dépôts continentaux du Jurassique inférieur affleurent rarement, l'histoire des dinosaures sauropodes est très mal connue avant la radiation des néosauropodes au Jurassique moyen. Les premiers crânes de sauropodes associés à des restes osseux bien préservés datent ainsi du Jurassique moyen. Nous rapportons ici la découverte, dans le Jurassique inférieur du Haut Atlas marocain, du squelette et du crâne d'un nouveau sauropode. Tazoudasaurus naimi n.g., n.sp. est le groupe frère de Vulcanodon et le sauropode basal le plus complet connu à l'heure actuelle.

\footnotetext{
* Corresponding author.

E-mail address: ronan_allain@yahoo.fr(R. Allain).
} 


\section{Version française abrégée}

Nous décrivons ici le squelette d'un nouveau sauropode, incluant des restes crâniens, récolté dans des pélites recouvrant des bancs carbonatés marins datés de la fin du Jurassique inférieur, de la nappe de Toundoute du Haut Atlas, au Maroc [9,17,24] (Fig. 1). Des restes de dinosaures théropodes de grande et de moyenne taille, mais d'affinités pour l'instant incertaines, ainsi que des débris de végétaux, essentiellement constitués de restes de fougères, de cycadales et de conifères, ont été découverts, associés aux restes de sauropode.

\section{Paléontologie systématique}

Dinosauria Owen, 1842

Saurischia Seeley, 1888

Sauropodomorpha Huene, 1932

Sauropoda Marsh, 1878

Vulcanodontidae Cooper, 1984

Tazoudasaurus naimi gen. et sp. nov.

Étymologie. Le nom de genre dérive de celui de la localité type Tazouda et de sauros, lézard en grec. Le nom spécifique vient de naïmi, élancé en arabe, et fait référence à la petite taille de l'holotype.

Holotype. To 2000-1, musée des Sciences de la Terre de Rabat, Maroc ; squelette partiellement articulé comprenant du matériel crânien, qui inclut une mandibule gauche complète, carré, jugal, postorbitaire, pariétal, frontal et exoccipital.

Autre spécimen. To 2000-2, restes associés d'un spécimen juvénile.

Localité et Horizon. Douar de Tazouda, près du village de Toundoute, dans la province de Ouarzazate, Haut Atlas, Maroc. Nappe de Toundoute, série continentale détritique du Toarcien, qui recouvre en concordance des carbonates marins datés du début et du milieu du Jurassique inférieur.

Diagnose. Sauropode primitif, défini par les autapomorphies suivantes (Fig. 2a-n) : lame osseuse s'étendant sur la marge postérodorsale du postorbitaire ; chevrons distaux bifurqués avec des processus antérieurs et postérieurs non fusionnés ; présence d'une crête sur la face latérale de l'extrémité proximale de la fibula. Tazoudasaurus présente aussi une combinaison unique de synapomorphies de sauropode (préarticulaire étendu dorsoventralement; couronne dentaire vue en coupe, en forme de D ; émail dentaire plissé ; centrum des vertèbres cervicales opisthocoele; large épine neurale dorsale ; quadrupédie obligatoire ; crête deltopectorale de l'humérus réduite, rapport humérus/fémur supérieur à 0,60 ; diaphyse fémorale elliptique en coupe ; absence de foramens à la base du processus ascendant de l'astragale ; phalange unguéale du premier doigt du pied en forme de faucille) et de symplésiomorphies de sauropodomorphe (20 dents dentaires, avec des denticules sur les marges antérieure et postérieure de la couronne dentaire ; extrémité antérieure du dentaire peu étendue dorsoventralement ; rangées dentaires convergentes en forme de $\mathrm{V}$; absence de fosse quadratique postérieure ; présence d'un petit trochanter sur le fémur ; surface plantaire des phalanges unguéales des doigts II et III aplatie).

Tazoudasaurus se différencie de Barapasaurus $[13,14]$ et de Kotasaurus [33,34] du Jurassique inférieur d'Inde, et de Gongxianosaurus [11] du Jurassique inférieur de Chine, sur la base de nombreux caractères anatomiques. Il présente, en revanche, beaucoup plus d'affinités avec Vulcanodon, du Jurassique inférieur du Zimbabwe [5,23], duquel il diffère cependant par l'absence de sillon médian sur la face ventrale des vertèbres dorsales et par des épines neurales caudales plus allongées antéropostérieurement. Une analyse phylogénétique incluant 29 taxons, dont les genres marocains Tazoudasaurus et Atlasaurus, a été réalisée. Les 235 caractères utilisés dans cette analyse sont tirés de la récente phylogénie de Wilson [30], auxquels nous avons rajouté le caractère «surface articulaire proximale des doigts II et III du pied significativement plus large que haute », précédemment considéré comme une autapomorphie de Vulcanodon [31]. Ce caractère soutient la position de Tazoudasaurus comme groupe frère de Vulcanodon à l'extérieur des Eusauropoda, dans les six arbres les plus parcimonieux obtenus, 
après utilisation de la commande mhennig*, $b b^{*}$ du logiciel Hennig86 [8] (Fig. 3). Les récentes datations effectuées sur les basaltes du plateau du Karoo montrent que Vulcanodon serait contemporain de Tazoudasaurus [7,15], même si de nombreux auteurs continuent à le placer dans le Jurassique basal (Hettangien) [3-5,10,13,23,28,30,32]. Les deux taxons sont regroupés ici au sein de la famille monophylétique des Vulcanodontidae, qui exclut les autres sauropodes connus au Jurassique inférieur [5,25,26,32].

Atlasaurus imlakei du Jurassique moyen (Bathonien) du Haut Atlas central [20,21] est le groupe frère des Neosauropoda (Fig. 3) [30] et est donc beaucoup plus dérivé que Tazoudasaurus. La succession, dans le Haut Atlas, de ces deux taxons montre que des changements majeurs interviennent dans la morphologie des sauropodes durant les 20 millions d'années qui séparent le Toarcien du Bathonien. Certains de ces changements semblent liés à l'alimentation (perte de la fenêtre mandibulaire externe, robustesse mandibulaire accrue au niveau de la symphyse, forme en $\mathrm{U}$ de la symphyse, réduction du nombre de dents), alors que d'autres peuvent être reliés à la locomotion et à la taille du corps (configuration en arche des métacarpiens, extension transversale de l'extrémité proximale du tibia et changement d'orientation de la crête cnémiale, forme en faucille des phalanges unguéales du pied).

Tazoudasaurus est le sauropode primitif le plus complet connu à ce jour. En tant que tel, il partage de nombreux caractères primitifs avec les prosauropodes, tels que l'absence de fosse quadratique, une faible extension dorsoventrale de l'extrémité antérieure de la mandibule, un nombre important de dents qui ne se recouvrent pas, la rétention d'un petit trochanter sur le fémur, une crête cnémiale orientée antérieurement ou de longues phalanges au pied. Cette évolution en mosaïque des caractères typiques des prosauropodes vers des caractères propres aux sauropodes remet en question la position phylogénétique de certains sauropodomorphes primitifs au sein des Prosauropoda. Cette observation est en accord avec celles consécutives aux descriptions d'Isanosaurus du Rhétien de Thaillande [3] et d'Antetonitrus du Norien d'Afrique du Sud [35]. Ces deux genres montrent, en effet, que certains caractères, longtemps considérés comme des synapomorphies de sauropode (quadrupédie obligatoire, section elliptique du fémur), étaient déjà apparus au Trias supérieur.

\section{Introduction}

Sauropod remains were documented from the Middle Jurassic strata of the High Atlas Mountains in Morocco through the descriptions of 'Cetiosaurus' mogrebiensis [16] and Atlasaurus imelakei [20,21]. Recently, we collected a partly articulated sauropod skeleton, including cranial material, from the Early Jurassic of the High Atlas near Toundout, in the Province of Ouarzazate (Fig. 1). In this area, the entire Jurassic series, decoupled from its base, has been overthrusted to the south where it overlies the CretaceousEocene [17]. The two principal fossiliferous sites are near the summit of a detrital series about $300 \mathrm{~m}$ thick that conformably overlies early Lower Jurassic marine carbonates containing algal spheres, and benthic foraminiferal and mollusc shells [9,24]. The two sites, separated from each other stratigraphically by about $30 \mathrm{~m}$, are sedimentologically and palaeobotanically similar. Associated with the sauropod material were isolated elements of medium-sized and large theropods of uncertain affinities. Greenish, channel-filling silts and sands are preserved within a red, relatively unfossiliferous clastic sequence. Submacroscopic woody debris include homoxylous particles devoid of parenchyma, evenly distributed uniseriate rays, tracheids bordered by uniseriate pits of abietinian form, and cross-fields with piceoid oculipores bearing narrow, perpendicular slits. The anatomy suggests affinities with pinacean, abietoidean or taxacean conifers. $\mathrm{Nu}$ merous, tiny fragments of vegetal material scattered through the sediment were derived from fern and, less frequently, cycad pinnulae. Although fragments of cuticle were common, no palynomorphs were recovered. The local flora was apparently dominated by ferns, cycads and conifers.

\section{Systematic palaeontology}

Dinosauria Owen, 1842

Saurischia Seeley, 1888

Sauropodomorpha Huene, 1932

Sauropoda Marsh, 1878

Vulcanodontidae Cooper, 1984

Tazoudasaurus naimi gen. et sp. nov. 

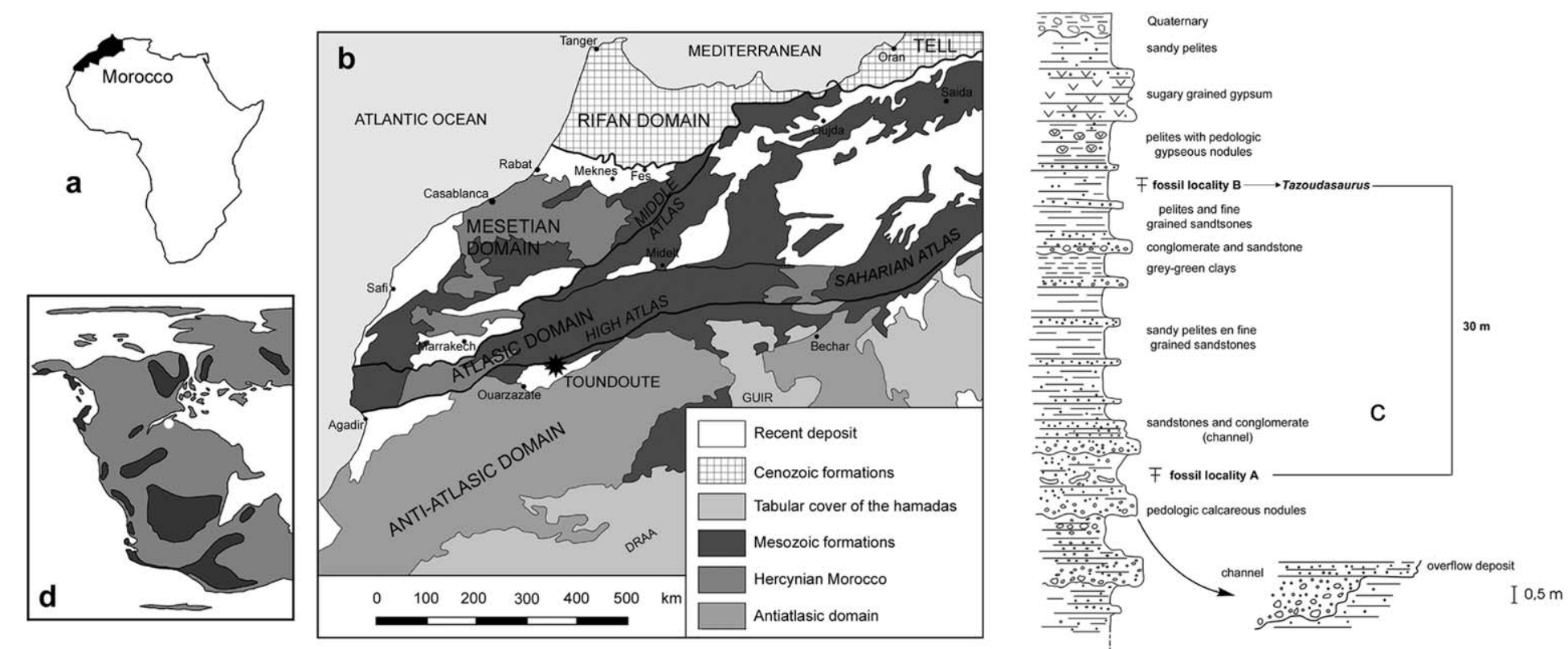

Fig. 1. (a, b) Geographic location; (c) stratigraphic section of the Toundoute fossil site (white point), in Ouarzazate province, Morocco; (d) Early Jurassic palaeogeographical map. Fig. 1. (a, b) Localisation géographique; (c) coupe stratigraphique du site fossilifère de Toundoute (point blanc), dans la province de Ouarzazate, Maroc ; (d) carte paléogéographique du Jurassique inférieur. 
Etymology. Generic name is from the type locality of Tazouda, plus sauros, Greek for lizard. Specific name from naimi, Arabic, masculine, for slender, referring to the small size of the holotype.

Holotype. To 2000-1, 'Musée des Sciences de la Terre', Rabat, Morocco, partially articulated skeleton and cranial material including complete left mandible with teeth, quadrate, jugal, postorbital, parietal, frontal and exoccipital.

Referred specimen. To 2000-2, associated remains of a juvenile skeleton.

Locality and horizon. Douar of Tazouda near Toundoute village in the Province of Ouarzazate, High Atlas of Morocco. Toundoute overthrust, Toarcian continental detrital series concordantly overlying early to middle Lower Jurassic marine carbonates.

Diagnosis. A primitive sauropod displaying the following autapomorphies: a thin bony plate extending from posterodorsal margin of postorbital; distal chevrons forked with unfused anterior and posterior processes, prominent crest on the lateral surface of the proximal end of the fibula. Moreover, Tazoudasaurus exhibits a unique combination of sauropod synapomorphies (see below) and sauropodomorph symplesiomorphies including: 20 dentary teeth with denticulate crown margins; anterior end of the dentary only slightly expanded relative to depth of dentary at midlength (Fig. 2a-b); dentaries meet in a V-shaped symphysis; posterior fossa absent on quadrate (Fig. 2c); lesser trochanter present laterally on femur; flat pubic apron; plantar surface of pedal unguals II-III flattened (Fig. 2m).

Preliminary description. Tazoudasaurus (Fig. 2) was a small, 9-m-long sauropod. A left mandible, originally $\sim 40 \mathrm{~cm}$ long, was broken at the level of the last dentary alveolus and its posterior portion was rotated dorsally relative to the tooth row (Fig. 2a-b). The mandible resembles that of a prosauropod. The $20 \mathrm{al}-$ veoli occupy the entire length of the dentary. The tooth row is only slightly arched anteriorly and the symphysis is not ' $U$ '-shaped as in other sauropods. The tooth crowns do not overlap. The teeth are spatulate and 'D'-shaped in cross-section. Denticles are present on both anterior and posterior carinae (Fig. 2e-f). The teeth bear ' $\mathrm{V}$ '-shaped wear facets indicating tooth-totooth occlusion and suggest that, contrary to previous reports, 'vulcanodontids' used oral processing in feed- ing [27]. A large external mandibular fenestra is present. The ventral process of the postorbital is narrow transversely; the element contacts the squamosal posteriorly through a thin bony plate (Fig. 2k). The parietal forms the entire medial border of a transversely elongated supratemporal fenestra. There is no quadratic fossa on the posterior surface of the quadrate (Fig. 2c).

Cervical centra are elongate and opisthocoelous. The lateral surface of the axis centrum is excavated but there are no true pleurocoels. The odontoid process projects forward from the centrum, but is not fused to it. The neural arch extends the full length of the centrum and broadens transversely posteriorly. The undivided neural spine is short, but extends the full length of the arch. A strong lamina projects anteriorly from the postzygapophysis toward the diapophysis, but does not reach it, in contrast to conditions in other sauropods $[19,34]$. The mid-dorsal centra are amphicoelous and bear large lateral depressions (Fig. 2g). Their length, diameter and height are nearly equal. The dorsal neural spines are slightly posteriorly inclined, and are broader transversely than anteroposteriorly. The rod-like transverse processes are directed laterally and upward. The architecture of dorsal neural arch includes the six diapophyseal laminae, including an anterior centroparapophyseal lamina, a prezygoparapophyseal lamina, centrozygapophyseal laminae and spinozygapophyseal laminae [29]. The spinodiapophyseal and spinopostzygapophyseal laminae do not contact each other. The caudal centra are amphicoelous and medially constricted. The anterior caudal centra are as long as they are high, whereas the mid- and posterior caudal centra are twice long as high. The neural arches extend the full length of the centra. The neural spine of the anterior and mid caudals is nearly perpendicular to the neural canal, whereas in the distal caudals it is strongly inclined posteriorly.

The haemal canal on the chevrons is bridged dorsally. The middle chevrons exhibit the typical Y-shaped morphology. The distal chevrons are forked and bear unfused anterior and posterior projections.

The pelvis and hindlimb of Tazoudasaurus are reminiscent of those of Vulcanodon [5,23]. The pubis is $53 \%$ of the femur length (Fig. 2h). The pubic apron is transversely oriented and the pubic symphysis is straight. The ambiens process is poorly developed. The 

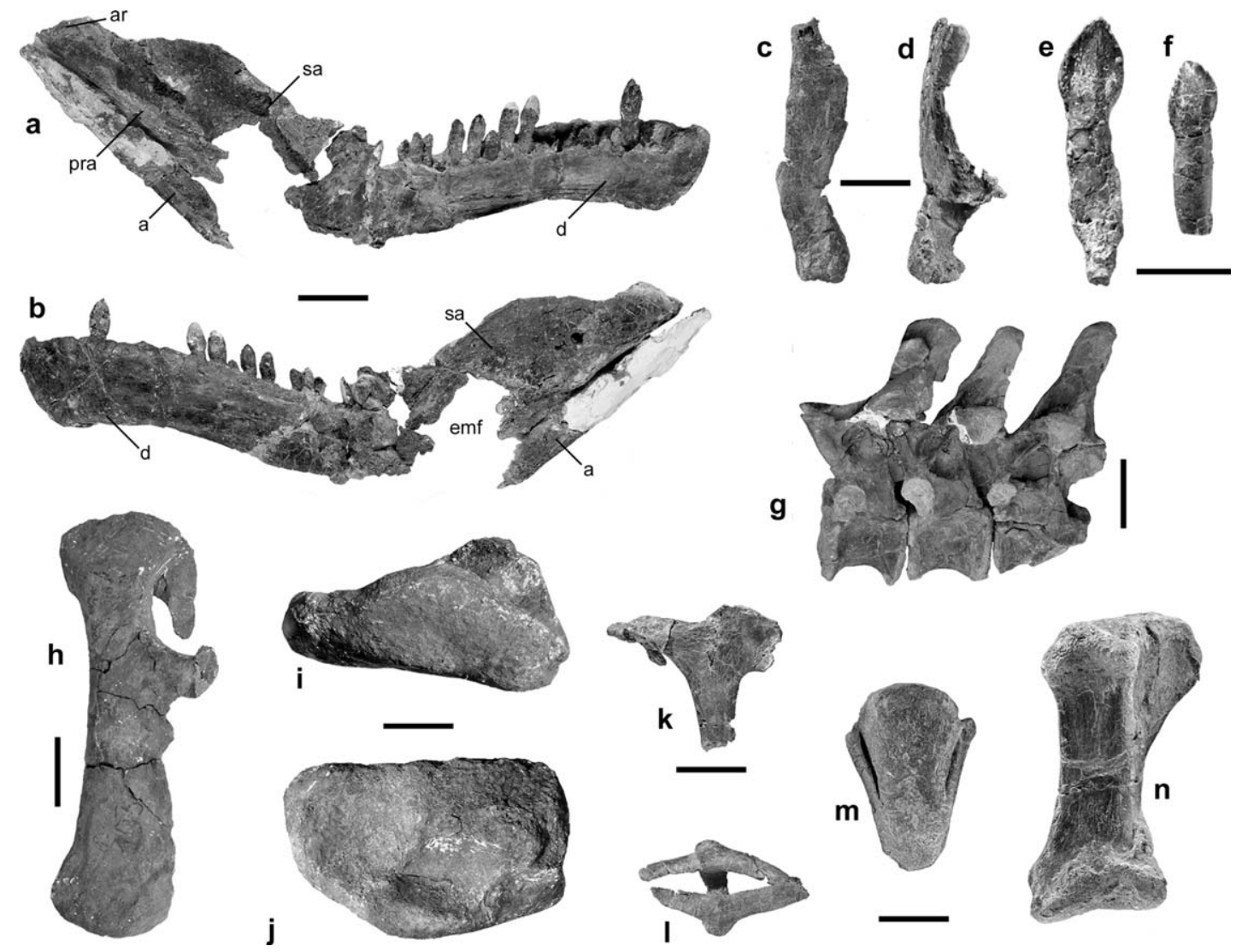

Fig. 2. Elements of the holotypic material of Tazoudasaurus naimi. (a, b) Left mandible in medial (a) and lateral (b) views; (c, d) right quadrate in posterior (c) and lateral (d) views; (e, f) serrated teeth in lateral (e) and medial (f) views; (g) dorsal vertebrae in left lateral view; (h) right pubis in anterior view; (i, j) right astragalus in ventral (i) and posterodorsal (j) views; (k) left postorbital in lateral view; (I) distal chevron in ventral view; (m) ungual phalanx of pedal digit II in dorsal view; (n) left metatarsal II in dorsal view. Scale bars are $10 \mathrm{~cm}(\mathbf{g}, \mathbf{h}) ; 4 \mathrm{~cm}(\mathbf{a}, \mathbf{b}, \mathbf{i}, \mathbf{j}, \mathbf{l}, \mathbf{n})$; $3 \mathrm{~cm}(\mathbf{c}, \mathbf{d}, \mathbf{k})$, and $1 \mathrm{~cm}(\mathbf{e}, \mathbf{f})$. a, angular; ar, articular; asp, ascending process; d, dentary; emf, external mandibular fenestra; pra, prearticular; sa, surangular.

Fig. 2. Éléments de l'holotype de Tazoudasaurus naimi. (a, b) Mandibule gauche en vues médiale (a) et latérale (b); (c, d) carré droit en vues postérieure $(\mathbf{c})$ et latérale $(\mathbf{d}) ;(\mathbf{e}, \mathbf{f})$ dents en vues latérale $(\mathbf{e})$ et médiale $(\mathbf{f}) ;(\mathbf{g})$ vertèbres dorsales en vue latérale gauche ; (h) pubis droit en vue antérieure ; (i, j) astragale droit en vues ventrale (i) et postérodorsale $(\mathbf{j}) ;(\mathbf{k})$ postorbitaire gauche en vue latérale ; (l) chevron distal en vue ventrale ; $(\mathbf{m})$ phalange unguéale du doigt II du pied en vue dorsale ; (n) métatarsien II gauche en vue dorsale. Barres d'échelle : $10 \mathrm{~cm}(\mathbf{g}, \mathbf{h})$; $4 \mathrm{~cm}(\mathbf{a}, \mathbf{b}, \mathbf{i}, \mathbf{j}, \mathbf{l}, \mathbf{n}) ; 3 \mathrm{~cm}(\mathbf{c}, \mathbf{d}, \mathbf{k})$ et $1 \mathrm{~cm}(\mathbf{e}, \mathbf{f}) . \mathbf{a}$, angulaire ; $\mathbf{a r}$, articulaire ; asp, processus ascendant ; d, dentaire; emf, fenêtre mandibulaire externe ; pra, préarticulaire; sa, surangulaire.

femur is straight, approximately $115 \mathrm{~cm}$ long, and elliptical in cross-section at midshaft. A lesser trochanter is present on the lateral surface of the femur in the juvenile specimen. The proximal condyle of the tibia is expanded anteroposteriorly, and bears an anteriorly projecting cnemial crest. The fibula is a slender bone measuring $67 \mathrm{~cm}$ in length. Its proximal end is triangular in outline, and the medial surface is broad and flat. A 20-cm-long lateral crest, which is absent in Vulcanodon, and an inturned anteromedial crest de- limit a large depression on the anterolateral surface of the fibula. The distal end is expanded anteroposteriorly and projects medially to contact the astragalus. The astragalus is rectangular and robust (Fig. $2 \mathrm{i}-\mathrm{j}$ ). The ascending process is abbreviated posteriorly. The articular fossa for the tibia is divided by a low crest, and a prominent tongue encircled the distal end of the tibia. The first pedal phalanges of each digit are longer than broad, the reverse of conditions in the remaining phalanges. The first ungual is deeper than wide and sickle- 
shaped, as in other sauropods, but unguals II-III are significantly broader than high with a nearly flat plantar surface, as in Vulcanodon [5,23] (Fig. 2m).

\section{Discussion}

Other well-preserved Early Jurassic sauropod skeletons, which are diagnostic at the generic level, include those of Barapasaurus [13,14] and Kotasaurus [33,34] from the Indian Kota Formation, Vulcanodon from the Zambezi Valley in Zimbabwe [5,23], and Gongxianosaurus from the Ziliujing Formation of China [11]. Barapasaurus can be separated from Tazoudasaurus by the peculiar morphology of the neural arch of the dorsal vertebrae (i.e., the development of concavities on the anterior and posterior faces of the posterior dorsal neural arches; and a infradiapophyseal pneumatopore on the middle and posterior dorsal neural arches), the absence of lesser trochanter on the femur and the laterally projecting cnemial crest. Among the characters that distinguish Tazoudasaurus from Kotasaurus [34] are the spinodiapophyseal laminae on the dorsal vertebrae, the anterior and posterior marginal tooth denticles, the square-shaped caudal centra, and the limited proximal expansion of the pubes in the former genus. A low dentary-tooth count, the absence of serrations on dental crowns, platycoelous cervical centra, the longer than high dorsal neural spines and the ungual morphology of Gongxianosaurus separate it from Tazoudasaurus. Minimally, Tazoudasaurus differs from Vulcanodon in lacking a ventral groove on the caudal centra, and in possessing caudal neural spines that are more elongated anteroposteriorly.

We conducted a phylogenetic analysis with 29 ingroup taxa, including the Moroccan genera Tazoudasaurus and Atlasaurus. The 235-character dataset used in our analysis is after the recent sauropod phylogeny of Wilson [30], to which we add the character 'proximal dimensions of pedal digits II and III significantly broader then deep', previously recognized as an autapomorphy of Vulcanodon [31] (see supplementary information). This character supports the placement of Tazoudasaurus as the sister taxon of Vulcanodon, outside the eusauropods (Fig. 3), using the mhennig*, bb* option of Hennig86 [8]. Tazoudasaurus also exhibits a set of sauropod plesiomorphic characters, otherwise

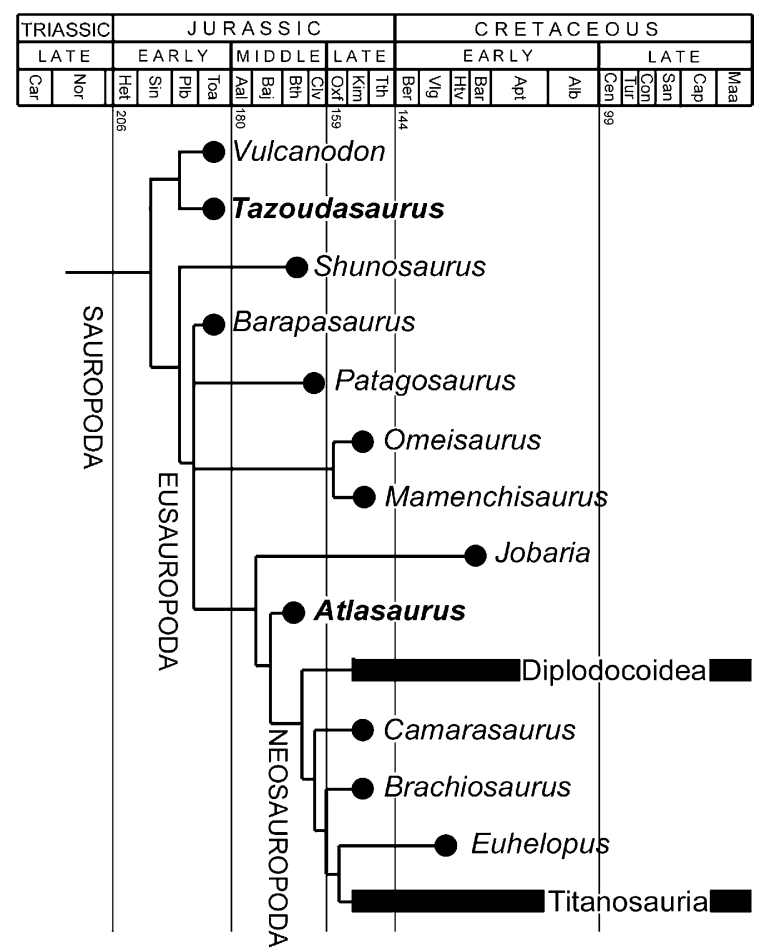

Fig. 3. Phylogenetic relationships of Tazoudasaurus and Atlasaurus within Sauropoda. Shown is the strict consensus tree of the six most parsimonious trees (tree length $=422$; consistency index $=0.61$; retention index $=0.78$ ). The 235 characters were drawn from the most recent sauropod phylogeny [15]. The tree was produced using the mhennig*, bb* option of Hennig86 [8].

Fig. 3. Relations phylogénétiques de Tazoudasaurus et d'Atlasaurus au sein des sauropodes. Arbre de consensus strict des six arbres les plus parcimonieux $(L=422 ; C I=0,62 ; R I=0,78)$. Les 235 caractères utilisés sont tirés de la phylogénie des sauropodes la plus récente. Cet arbre a été obtenu par l'intermédiaire de la commande mhennig*, bb* d'Hennig86 [8].

known only in Vulcanodon: flat pubic apron, lesser trochanter present on femur, nonungual pedal phalanges longer than broad, and flat plantar surface on pedal unguals II and III. Although widely considered to be of basal Jurassic age (Hettangian) [3-5,10,13,23,28, 30,32], recent dates support a Toarcian (late Early Jurassic) age for the Karoo basalts [7,15], thereby rendering Vulcanodon a contemporary of Tazoudasaurus. Both taxa are placed within the monophyletic family Vulcanodontidae to the exclusion of other primitive sauropods, such as Barapasaurus[13,14], Kotasaurus [33,34] and Shunosaurus [6] (Fig. 3). Vulcanodontidae was originally created by Cooper to include Vulcanodon and Barapasaurus [5]. Such a grouping is now widely considered as paraphyletic 
$[25,26,32]$, and Vulcanodontidae is redefined here as all sauropods closer to Vulcanodon than to eusauropods (i.e. Vulcanodon and Tazoudausaurus). Derived characters of Tazoudasaurus shared with other sauropods include: dorsoventrally expanded prearticular, crown-to crown occlusion, D-shaped crowns, wrinkled enamel surfaces, opisthocoelous cervical centra, broad dorsal neural spines, obligately quadrupedal posture, humeral deltopectoral crest reduced to a ridge, humerus-to-femur ratio greater than 0.60 , reduced femoral fourth trochanter, femoral midshaft with elliptical cross section, foramina absent near base of ascending process of astragalus, pedal digit I $25 \%$ longer than pedal digit II and sickle-shaped pedal ungual I.

As previously suggested [30], Atlasaurus imlakei from the Bathonian of the central High Atlas [20,21] is the sister taxon to a diversified neosauropod clade (Fig. 3). In less than 20 million years, between late Early Jurassic (Toarcian) and Middle Jurassic (Bathonian) time, major changes evidently occurred in sauropod morphology as shown in Moroccan specimens Tazoudasaurus and Atlasaurus. Some were related to feeding, such as the loss of the external mandibular fenestra, increase of mandibular robustness towards the symphysis, anteriorly U-shaped tooth rows and reduction in the number of teeth. Others were related to locomotion and body size [31], such as the tightly arched configuration of the metacarpus, transversely expanded proximal condyle of the tibia with a laterally directed cnemial crest, wedge-shaped astragalus and sickle-shaped pedal unguals.

As the most primitive and relatively completely known sauropod, Tazoudasaurus augments our understanding of basal sauropod features, and resets some previously ambiguous eusauropod synapomorphies to the base of the sauropod clade [26,30]. Nevertheless, like Vulcanodon, Tazoudasaurus still shares many primitive characters with prosauropods, including the absence of quadratic fossa, the slightly expanded anterior end of the dentary, the high dentary-tooth count, the V-shaped tooth rows, the non-overlapping tooth crowns, the lesser trochanter on the femur, the anteriorly projecting tibial cnemial crest and the long pedal phalanges. Although a phylogenetic analysis of prosauropods is beyond the scope of this paper, this mosaic transition from prosauropod to sauropod features challenges the phylogenetic position of certain sauropodomorph taxa within Prosauropoda. This is con- sistent with the recent description of Antetonitrus ingenipes from the Lower Elliot Formation of South Africa, which documents the acquisition of certain key sauropod characters, such as a quadrupedal posture, large humero-femoral ratio and elliptical femoral midshaft, as early as the Late Triassic [35]. If graviportal sauropod adaptations began to appear during the Late Triassic, as shown by the morphology of Antetonitrus [35] and Isanosaurus [3] from the Rhaetian of Thailand, the evolution towards a more derived eusauropod condition was not complete before the end of the Early Jurassic time, as suggested by the retention of some primitive sauropodomorph characters in Tazoudasaurus.

Skeletal parts of a sauropod originally $\sim 13 \mathrm{~m}$ long and weighing $\sim 15$ tonnes have been identified in the Rhaetian (Late Triassic) of Thailand [2,4,19], and trackways of equally large sauropods occur in Pliensbachian (Middle Liassic) carbonates in Morocco [12]. In contrast to an apparently abrupt increase in theropod size across the Triassic-Jurassic boundary [22], sauropods had already become gigantic in the Rhaetian $[4,18]$ and continued to be gigantic through to the end of the Mesozoic. Thus, Tazoudasaurus was surpassed in size by other contemporary sauropods. The record of Early and Middle Jurassic sauropods is exceptionally rich in Morocco, but unknown in North America [28]. Because sea-floor spreading along the central Atlantic axis did not begin until early in Middle Jurassic time (Fig. 1d) [1], the Moroccan dinosaur record probably samples an assemblage that also inhabited North America.

\section{Supplementary information}

Supplementary information accompanies the paper on website (http://www.sciencedirect.com).

\section{Acknowledgements}

The field excavations in Morocco were supported by the Ligabue Foundation (Venice, Italy); we thank Giancarlo Ligabue for his generosity. We also thank Mr Mohammed Sadiqui and Mr Larbi Tabit from the 'Ministère de l'Énergie et des Mines' of Morocco for permission to conduct fieldwork and for logistic support from their Institution. We thank Moha M'ghari for 
his skilful preparation of the material, Philippe Loubry and Denis Serrette for photographs and the Moroccan people for their help and generous hospitality. We are grateful to Michael Raath for counsel on the age of Vulcanodon, and Pierre Stine and Gedeon Films for providing heavy equipment to assist in the excavations. English translations of Chinese papers cited in this article are available at The Polyglot Paleontologist website.

\section{References}

[1] M. Amrhar, M. Bouabdelli, A. Piqué, Les marqueurs structuraux et magmatiques de l'extension crustale dans le Haut-Atlas occidental (Maroc) au Dogger, témoins de l'évolution de la marge orientale de l'Atlantique central, C. R. Acad. Sci. Paris, Ser. IIa 324 (1997) 119-126.

[2] J.F. Anderson, A. Hall-Martin, D.A. Russell, Long-bone circumference and weight in mammals, birds and dinosaurs, J. Zool. Lond. 207 (1985) 53-61.

[3] E. Buffetaut, V. Suteethhorn, G. Cuny, H. Tong, J. Le Loeuff, S. Khansubha, S. Jongautchariyakul, The earliest known sauropod dinosaur, Nature 407 (2000) 72-74.

[4] E. Buffetaut, V. Suteethorn, J. Le Lœuff, G. Cuny, H. Tong, S. Khansubha, The first giant dinosaurs: a large sauropod from the Late Triassic of Thailand, C. R. Palevol 1 (2002) 103-109.

[5] M.R. Cooper, A reassessment of Vulcanodon karibaensis Raath (dinosauria: Saurischia) and the origin of the Sauropoda, Palaeontol. Afr. 25 (1984) 203-231.

[6] Z. Dong, S. Zhou, Y. Zhang, The dinosaurian remains from Sichuan Basin, China, Palaeontol. Sinica 23 (1983) 1-145.

[7] R.A. Duncan, P.R. Hooper, J. Rehacek, J.G. Marsh, A.R. Duncan, The timing and duration of the Karoo igneous event, southern Gondwana, J. Geophys. Res. 102 (1997) 127-138.

[8] J.S. Farris, Hennig86, Port Jefferson station, New York, 1988 Version 1.5.

[9] P. Fallot, L. Moret, E. Roch, Sur la série liasique du pays de Skoura (Haut-Atlas marocain), C. R. Acad. Sci. Paris 199 (1934) 1135-1138.

[10] D.D. Gillette, The geographic and phylogenetic position of sauropod dinosaurs from the Kota formation (Early Jurassic) of India, J. Asian Earth Sci. 21 (2003) 683-689.

[11] X.-L. He, C.-S. Wang, S.-Z Liu, F.-Y. Zhou, T.-Q. Liu, K.-J. Cai, B. Dai, A new sauropod dinosaur from the Early Jurassic in Gongxian County, south Sichuan, Acta Geol. Sichuan 18 (1998) 1-6.

[12] S. Ishigaki, Les empreintes de dinosaures du Jurassique inférieur du Haut-Atlas central marocain, Notes Mém. Serv. Géol. Maroc 44 (1988) 79-86.

[13] S.L. Jain, T.S. Kutty, T. Roy-Chowdhury, S. Chatterjee, The sauropod dinosaur from the Lower Jurassic Kota formation of India, Proc. R. Soc. Lond. 188 (1975) 221-228.
[14] S.L. Jain, T.S. Kutty, T. Roy-Chowdhury, S. Chatterjee, Some characteristics of Barapasaurus tagorei, a sauropod dinosaur from the Lower Jurassic of Deccan, India, IV Int. Gondwana Symp., Calcutta, India, 1, 1979, pp. 204-216.

[15] D.L. Jones, R.A. Duncan, J.C. Briden, D.E. Randall, C. MacNiocaill, Age of the Bakota basalts, northern Zimbabwe, and the duration of Karoo Large igneous province magmatism, Geochem. Geophys. Geosyst. 2 (2001) 2000GC000110.

[16] A.F. de Lapparent, Étude paléontologique des vertébrés du Jurassique d'El Mers (Moyen Atlas), Notes Mém. Serv. Géol. Maroc 124 (1955) 1-36.

[17] E. Laville, J.-L. Lesage, M. Séguret, Géométrie, cinématique (dynamique) de la tectonique atlasique sur le versant sud du Haut Atlas marocain. Aperçu sur les tectoniques hercyniennes et tardi-hercyniennes, Bull. Soc. géol. France 29 (1977) 527 539.

[18] M.G. Lockley, J.L. Wright, A.P. Hunt, S.G. Lucas, The Late Triassic sauropod track record comes into focus: old legacies and new paradigms, New Mexico Geol. Soc. Guidebook 52 (2001) 181-190.

[19] J.H. McIntosh, C.A. Miles, D.A. Cloward, J.R. Parker, A new nearly complete skeleton of Camarasaurus, Bull. Gunma Mus. Nat. Hist. 1 (1996) 1-87.

[20] M. Monbaron, P. Taquet, Découverte du squelette complet d'un grand Cétiosaure (Dinosaure Sauropode) dans le bassin jurassique moyen de Tilougguit (Haut-Atlas central, Maroc), C. R. Acad. Sci. Paris, Ser. II 292 (1981) 243-246.

[21] M. Monbaron, D.A. Russell, P. Taquet, Atlasaurus imelakei, n.g., n.sp., a brachiosaurid-like sauropod from the Middle Jurassic of Morocco, C. R. Acad. Sci. Paris, Ser. IIa 329 (1999) 519-526.

[22] P.E. Olsen, D.V. Kent, H.-D. Sues, C. Koeberl, H. Huber, A. Montanari, E.C. Rainforth, S.J. Fowell, M.J. Szajna, B.W. Hartline, Ascent of dinosaurs linked to an iridium anomaly at the Triassic-Jurassic boundary, Science 296 (2002) 1305-1307.

[23] M.A. Raath, Fossil vertebrate studies in Rhodesia: a new dinosaur (Reptilia: Saurischia) from near the Trias-Jurassic boundary, Arnoldia 5 (1972) 1-37.

[24] E. Roch, Description géologique des montagnes à l'Est de Marrakech, Notes Mém. Serv. Mines Carte géol. Maroc 80 (1939) 1-438.

[25] P. Upchurch, The evolutionary history of sauropod dinosaurs, Phil. Trans. R. Soc. Lond., Ser. B 349 (1995) 365-390.

[26] P. Upchurch, The phylogenetic relationships of sauropod dinosaurs, Zool. J. Linn. Soc. 124 (1998) 43-103.

[27] P. Upchurch, P.M. Barrett, The evolution of sauropod feeding mechanisms, in: H.-D. Sues (Ed.), The Evolution of Herbivory in Terrestrial Vertebrates, Perspectives from the Fossil Record, Cambridge University Press, Cambridge, 2000, pp. 79-122.

[28] D.B. Weishampel, Sauropoda, in: D.B. Weishampel, P. Dodson, H. Osmólska (Eds.), The Dinosauria, Univ. California Press, Berkeley, CA, 1990, pp. 63-139.

[29] J.A. Wilson, A nomenclature for vertebral laminae in sauropods and other saurischian dinosaurs, J. Vert. Paleontol. 19 (1999) 639-653. 
[30] J.A. Wilson, Sauropod dinosaur phylogeny: critique and cladistic analysis, Zool. J. Linn. Soc. 136 (2002) 217-276.

[31] J.A. Wilson, M.T. Carrano, Titanosaurs and the origin of "wide gauge' trackways: a biomechanical and systematic perspective on sauropod locomotion, Paleobiology 25 (1999) 252-267.

[32] J.A. Wilson, P.C. Sereno, Early evolution and higher-level phylogeny of sauropod dinosaurs, Mem. Soc. Vert. Paleontol. 18 (1998) 1-68.
[33] P. Yadigiri, A new sauropod Kotasaurus yamanpalliensis from Lower Jurassic Kota Formation of India, Rec. Geol. Surv. India 11 (1988) 102-127.

[34] P. Yadigiri, The osteology of Kotasaurus yamanpalliensis, a sauropod dinosaur from the Early Jurassic Kota Formation of India, J. Vert. Paleontol. 21 (2001) 242-252.

[35] A.M. Yates, J.W. Kitching, The earliest known sauropod dinosaur and the first steps towards sauropod locomotion, Proc. R. Soc. Lond. B (2003) DOI 10.1098/rspb.2003.2417. 